\title{
SPATIAL ANALYSIS OF THE SOCIO-CULTURAL IMPACT OF SECOND HOME TOURISM. A CASE STUDY: APUSENI NATURE PARK (PART OF CLUJ COUNTY)
}

\author{
Ioana Alexandra CIUPE \\ Babeş-Bolyai University, Cluj-Napoca, Faculty of Geography, ROMANIA \\ alexandra.ciupe@yahoo.com \\ DOI: http://doi.org/10.23740/TID220193
}

\begin{abstract}
The impact of second home tourism has been one of the most researched topics in international literature. The main objective of this study is to assess the possible socio-cultural effects of second home tourism on the local community from a spatial perspective. Therefore, in order to achieve this goal, a spatial statistical analysis was performed using two variables: the distance of the vacation homes from the nearest buildings of the local people, and the density of vacation homes in the place in which they are located, respectively. The results show four different patterns of second home development in relation to the local community: areas with a low density of vacation homes, located a short distance from the local people's buildings; areas with a high density of vacation homes, located a short distance from the local people's buildings; areas with a high density of vacation homes, located a great distance from the local people's buildings; areas with a low density of vacation homes, located a great distance from the local people's buildings. The results were interpreted primarily in accordance with the literature, and secondly based on direct field observations. The evidence suggests that the socio-cultural impacts of second home tourism are significantly influenced by the spatial context.
\end{abstract}

Keywords: social impact, cultural impact, vacation homes, spatial statistics analysis

Cite this article as: Ciupe, I.Al. (2019). Spatial Analysis of the Socio-Cultural Impact of Second Home Tourism. A Case Study: Apuseni Nature Park (Part of Cluj County). Territorial Identity and Development, 4(2), 39-57. DOl: http://doi.org/10.23740/TID220193

\section{INTRODUCTION}

The second homes: curse or blessing? (Coppock, 1977) - is a suggestive question that has concerned over time many researchers in the field of second home development. Consequently, there exists a considerable body of literature on the possible impacts (i.e. social, cultural, economic, environmental) of second home development. Therefore, this paper begins with a short review of the literature regarding the socio-cultural impact of second home tourism on host communities. The second section shows the techniques and methods used. In the third section, a case study of Apuseni Nature Park (part of Cluj County) is presented. This section is divided into two parts: the first part shows the results of the spatial statistical analysis for the whole case study area, while the second part presents, at a much more detailed level, four examples of the second home patterns. The interpretation of the results was based on two main 
references: firstly, according to the literature presented below and secondly, based on direct field observations. In addition, some conclusions are drawn in the final section.

\section{THEORETICAL BACKGROUND}

Recently, researchers have shown a growing interest in the relationship between the concept of place attachment and the second home tourism phenomena. Therefore, starting from the premise that emotional ties to the place foster community development (Manzo \& Perkins, 2006), the degree and nature of the place attachment of second home owners to the host area has been raised in a number of recent works.

That is to say, due to the specific seasonality of this phenomena, the second home owners often get labels such as: outsiders, newcomers, non-locals (Borsdorf, Hidalgo \& Zunino, 2012; Cottyn, 2011; Gallent, 2014; Nordin \& Marjavaara, 2012), weekend residents (Halseth, 2004), snowbirds (McHugh \& Mings, 1996), summer people (Stedman, 2006). Consequently, according to Stedman (2006) (referring in particular to the summer people), such labels "confer an outsider status and suggest shallow and inauthentic connections" (p. 187). However, Trentelman (2009) points out with respect to the place attachment concept that "while seen as resulting from longterm interaction and experience with a place [...] some argue that at times, intensity of experience can serve as proxy for long exposure to the place" (p. 200). In this regard, a number of studies have found that the level of attachment to the place of second home owners is strong enough (Kaltenborn, 1997) or even higher than that of local residents (Hao \& Long, 2016; Stedman, 2006). Nevertheless, in all the cases listed above, the mode and factors that favour place attachment differ between the two groups.

Therefore, in general terms, together these studies show that second home owners tend to be more attached to the quality of the natural environment and the recreational aspects of the place, while permanent people are more concerned with issues related to the social and economic life of the community in which they spend their lives. However, these differences in perception of the place are suggestively labelled by some authors: home place vs. escape place (Stedman, 2006, p. 201), working landscape vs. landscape of leisure (Halseth, 2004, p. 52) or escape vs. work and 'everyday life' (Overvåg \& Berg, 2011, p. 419).

Consequently, these differences in the meaning of the place between the two groups can lead to an arena with different objectives, expectations and, finally, actions. Related to this matter, Overvåg \& Berg (2011) argue that sometimes second home owners and the inhabitants "share the same spaces, but use them for different purposes" (p. 419). Thereby, in the literature, such situations are often mentioned as potential sources of conflict between the two groups in question. For instance, several studies (see Jaakson, 1986; Kondo, Rivera \& Rullman, 2012; Marcouiller et al., 1996) have revealed that, in some cases, second home owners prevent future development in the host community. This seems to be primarily due to their desire to preserve the quality of the 'untouched' environment in the location of the second home. Conversely, in other areas, the second home owners seem to be more receptive to such initiatives, but only if the developments are "very tastefully done" (Dykes \& Walmsley, 2015, p. 107) or are not carried out in their vicinity, in other words, the owners display a 'not in my backyard' attitude (Farstad \& Rye, 2013). Moreover, some second home owners tend to resist even the development of large-scale tourism (Müller, Hall \& Keen, 2004, p. 22) or, according to Overvåg \& Berg (2011), 
there are situations in which they 'ally' with the local people to prevent the other future developments of second homes in the area.

In short, the literature suggests that identifying the different perceptions of the two groups concerned is an important desideratum in terms of community cohesion. Thereby, as Wilkinson (1991) states: "a clear understanding of what is important for residents of a community is central to the promotion of community development strategies guided by general community interest" (cited from Hao \& Long, 2016, "conclusion", para. 4).

Another topic discussed in the literature is the role and nature of social interaction and social capital in the context of second home development. Therefore, in some cases, the level of attachment of second home dwellings does not appear to be positively influenced by interaction with permanent residents (see Kaltenborn, 1997; Stedman, 2006). In contrast, MatarritaCascante, Stedman \& Luloff (2010) highlighted the relevance of social interactions with the family members and the neighbours, as well as the engaging in various local activities. Others (see Hao \& Long, 2016; Nordin \& Marjavaara, 2012) emphasized the predilection of second home owners to be involved in local associations. Overall, these studies underline a lack of interest of second home owners to a direct interaction with the local inhabitants.

Moreover, according to Gallent (2014), the relatively short length of stay in the host community "may act to limit the scope of social interactions and therefore their contribution to community building" (p. 181). However, he argues that second home owners can be considered the interconnectors between local communities and other valuable social and professional external environments.

Poor social interaction can also be fostered by spatial separation - the last representing another topic encountered in the literature related to second homes and their socio-cultural impacts on the local community. Therefore, a well-known example of spatial segregation of second homes is the 'snowbirds' enclaves in Arizona (United States of America) (see McHugh, 2006; McHugh, 2007; McHugh \& Mings, 1996; Sullivan \& Stevens, 1982). These seasonal retirements are distinguished by a strong attachment, collective identity, loyalty to the community to which they belong, but through poor interaction with the permanent population. Consequently, in some circumstances, they are referred to as "other" by the year-round residents (McHugh \& Mings, 1996, p. 541). Therefore, some authors (see Nordin \& Marjavaara, 2012, p. 296) note that the spatial segregation of second home owners and consequently, the lack of communication with the permanent residents, could strengthen the sense of "us and them".

In contrast, Overvåg \& Berg (2011) argue that a spatial separation of second homes from permanent settlements, in fact, provides a delimitation of "work and leisure 'situations"' and therefore possible conflicts between the two groups can be diminished (pp. 421-422). In the same vein, Rye (2011, p. 273) suggests that the optimal solution in this regard could be a great physical distance and a small social distance simultaneously between the year-round locals and the second home owners.

Further, social segregation between the two groups is another type of problem that can create conflicts within the host community. In general, the literature highlights a socio-economic difference between the two groups in question. According to Müller \& Hoogendoorn (2013), the notion of 'elite landscapes' is the most common in the Anglosphere literature (p. 359). Moreover, they claim that Central and Southern Europe also show a socio-economic discrepancy between second-home owners and locals (p. 359). For example, in a case study, Halseth (2004) found a socio-economic difference of vacation home owners, both compared to permanent residents in the host area and to the general Canadian population. According to the author, they 
usually have high incomes, a higher level of education and tend to be employed in professional occupations. All this, as he claims, solidifies the elite status.

On the other hand, the level of the accessibility to a second home in Northern European countries is much higher (Müller \& Hoogendoorn, 2013). In addition, because in these countries some of the rural people have their own cottages, the discrepancy between rural and urban dimension is more blurred (Farstad \& Rye, 2013, p. 45).

Another common topic regarding potential conflicts generated by second home tourism in host communities is related to the real estate market stock. Competition for the same stock of property is especially evident in attractive areas and can lead to inflation in house prices (Norris \& Winston, 2009) and, finally, to the displacement of the local population (Hall, 2014; Müller, Hall \& Keen, 2004). Therefore, according to Overvåg \& Berg (2011, p. 423), in order to minimize conflicts in host areas, the two markets should not overlap. However, referring to the phenomena of displacement, Marjavaara (2007) argues that, in some situations, second homes are used as a "convenient scapegoat" and that there are other issues that may underlie rural depopulation (e.g. economic restructuring) (p. 312).

Rural gentrification is another topic discussed in the literature (see Cottyn, 2011; Paris, 2009; Woods, 2005) in close relationship with the displacement phenomena. Thus, Woods (2005) mentions that rural gentrification caused by second homes phenomena can be manifested by speculative investments of middle-class urbanities, thus leading to price inflation and, finally, to the exclusion of low-income people.

Overdevelopment is perhaps one of the most important issues concerning the development of second homes. For example, Overvåg \& Berg (2011) associate high-density second homes areas located a short distance from permanent settlements with the possibility of increasing the level of conflict in the host community.

Thus, overdevelopment accompanied by the accentuated seasonality of second-home phenomena can also lead to what some authors call 'ghost towns' or 'ghost villages' (Litvin et al., 2013; Overvåg \& Berg, 2011; Shucksmith, 1983).

Also Müller, Hall \& Keen (2004) claim that the seasonality of the second home tourism can contribute to: democratic inequalities (e.g. in general, second home owners do not have the right to vote in the host community); disadvantages in the context of government funding by underestimating the actual population; increase of the crime rate.

Last but not least, lost traditions or cultural identity are another issue related to the development of second homes. Therefore, according to Marjavaara (2007), "second home owners are often targeted as holders of alien values not suited to the local rural community" ( $p$. 312) or, as Asgary, Rezvani \& Mehregan (2011) claim, they can lead to the "resentment within the local community and to a dilution of local culture" (p. 34). Also, Mika (2013) suggests that second home developments in the Polish Carpathians may cause, among other things, spatial and morphological changes in settlements and issues related to aesthetics and traditional architecture.

However, there are a number of positive impacts that should not be ignored. The most common examples refer to: "enhanced community lifestyle, input of new ideas into community, creation of facilities, increase in local pride in the area, preserves a traditional way of life, use of redundant housing stock" (Müller, Hall \& Keen, 2004, p. 29). Also, as noted by Rye (2011), the second home owners invest "their identities, loyalties and spare time in the hosting region, offers important resources that may be activated by the local population [...] provide access to 
important social networks that extend outside the municipality, perform roles as advocates and ambassadors for the locality in their urban environments, and introduce new knowledge and practices in the rural community" (p. 265). Similarly, Norris \& Winston (2009) have found that second home owners can add "a cosmopolitan dimension" to the host community, they tend to get involved in community organizations and sponsoring various events (p. 159).

In summary, following the literature review, the common situations that may cause conflicts between permanent and seasonal owners are related to: the sense of place and the difference in perceptions about the future developments; social interaction and social capital; spatial segregation; socio-economic differences; property markets; displacement; rural gentrification; overdevelopment; lost traditions or cultural identity. This is certainly not an exhaustive list, but it serves as a basis for interpreting our empirical results.

However, far too little attention has been paid to the relationship between spatial and morphological patterns of settlements and the socio-cultural effects of second home tourism on local communities at a detailed level. Consequently, the first major objective of this study is to demonstrate that, through an empirical and spatial statistical analysis of second homes and local people's buildings (using two variables - distance and density, and knowledge gained from the literature), we can obtain satisfactory results for identifying the possible socio-cultural impacts of residential tourism on the local community.

\section{METHODOLOGY}

Traditionally, the impacts of second home tourism has been assessed by surveys applied to second home owners and/or to local people (e.g. Dykes \& Walmsley, 2015; Farstad \& Rye, 2013; Hao \& Long, 2016; Matarrita-Cascante, Stedman \& Luloff, 2010) or by mixed-methods, combining diverse spatial data and interview analysis (e.g. Kondo, Rivera \& Rullman, 2012; Litvin et al., 2013). Therefore, in this study, was used a combination of quantitative and qualitative approaches.

In a first phase, a direct field research was made in order to identify the spatial location of each second home in Apuseni Nature Park (part of Cluj County). The identification of second homes was based on personal considerations and the help of the local people. Data management and analysis were performed using a geographic information system (GIS).

After collection, the data were digitized in a point shapefile using ArcGIS software. For this study, we chose to exclude from the analysis the commercial accommodation units and the second homes that have any kind of online promotion for rent (either owned by a local person or owned by an urban owner).

Following this, through using a basemap, the buildings of the local people were digitized in a point shapefile. Because the identification of permanent housing in all types of construction has been difficult to achieve, all buildings in the study area were taken into account. However, we consider that any type of construction represents the presence of the local community in a certain way.

After these steps, a raster image was built for both of the shapefiles: the Euclidean Distance function was used to provide the distance around the villagers' buildings and the Kernel Density 
function was used to identify the spatial density of vacation homes (the Kernel function was best suited for the expected results).

Further on, the values from the two rasters were automatically extracted in the layer that represents the vacation homes. Thus, now each point that represents a vacation home has two values assigned: the density of the vacation homes in the area where they are located, and the distance from the nearest building belonging to permanent settlements, respectively.

The last stage consisted in the application of a statistical spatial analysis - grouping analysis. The analysis had no spatial constraint, so the K-means algorithm was used. We decided that four clusters would best suit our purpose.

However, a further mention should be added. Because Euclidean Distance analysis does not take into account natural obstacles (in our case, Fântânele Reservoir), and in order to reduce the distortions of the results, the raster was developed in two parts: one for the localities in the northern area of the reservoir and one for the localities in the southern part of the reservoir.

For a simplified spatial representation of the overall results (see Figure 2), the mean center function was used. Also, for the representations of the patterns (Figures 3, 4, 5, 6), raster cells with slightly exaggerated cell size were used for a better visibility. Overall, the results were satisfactory.

The shapefile of administrative limits were taken from the official website of the National Agency for Cadastre and Advertising (2019), while the limit of the Apuseni Nature Park was taken from the official website of the Romanian Ministry of Environment, Water and Forests (2015).

Overall, a number of important limitations of this study need to be considered. Firstly, because in Romania there are very limited studies on second home tourism in general, and even less related to its socio-cultural impact on local communities, there is no possibility to compare the results of the study with other research at a regional and national level.

Also, given that the sample size is relatively small compared to the size of the phenomena at national level, these results cannot be generalized, therefore they have a strong local character. This local character is closely linked to the geographical, social, cultural, economic and administrative peculiarities of the study area, which may differ, for example, from cases of vacation home settlements in the low or coastal areas.

Another limitation is related to the methodology used. Therefore, given that, to our knowledge, this methodology has not been used in this field, we cannot make a comparison with other empirical results in the literature. Moreover, another potential problem is related to the subjective nature of the process of collecting data directly from the field. Thus, due to the seasonality of second home tourism and the particular pattern of visiting, finding the owners in the case study area was sometimes difficult to achieve. In addition, not all second home owners were open to conversation. Consequently, because vacation homes have been identified largely - based on our own considerations, there may be some errors.

Moreover, another issue is related to the calculation of the Euclidean Distance of vacation homes from local communities. In this regard, because the Euclidean Distance does not take into account natural obstacles or, for example, the actual route on an asphalt road or forest road, the distances are only approximate. 


\section{RESULTS AND DISCUSSION}

The study area is located in north-western Romania, in Cluj County - one of the three counties covered by the Apuseni Natural Park. It represents a rural area included in the geographical region of the Apuseni Mountains, with a high concentration of tourist attractions of national and international interest. Consequently, it is declared a protected area in the V IUCN category, which has as main objective the protection of nature and the conservation of the natural and cultural landscape (Dudley, 2013).

However, according to Surd et al. (2014), the settlements in the Apuseni Mountains region have experienced a continuous process of depopulation especially after 1990 (p. 8). Moreover, the same authors claim that the area is unable to maintain a balanced demographic stock because of the current basic activities such as: the forest exploitation, the extensive pastoral agriculture and the "weak economic successes resulting from tourist activities" (Surd et al., 2014, p. 8).

With all this, the region has a strong cultural identity. For example, one of its peculiarities consists in the high-altitude habitation (Surd et al. 2014; Surd, Constantin \& Nicula, 2017). Also, in terms of morphology, the settlements encountered in the Apuseni Mountains are divided into three main categories: nucleated, scattered and dispersed (Conea, 1937; Surd, Constantin \& Nicula, 2017).

The study area includes seven villages (Beliș, Bălcești, Dealu Botii, Smida, Poiana Horea, and Giurcuța de Sus) - all from Beliș Commune, half of the village Dealul Negru (Călățele Commune), and two hamlets (Ic Ponor and Doda Pilii), respectively - the last belonging to Mărgău Commune and Fântânele Resort (Râșca Commune). All above-mentioned types of settlements morphologies can be found in our study area.

Moreover, due to the qualities of the natural environment, the area has attracted a number of vacation home owners from nearby urban centres (many of them have their main residence in the urban centres of Cluj County). For instance, according to the Census of Population and Housing of 2011 - Romania, the total number of vacation homes in Beliș Commune is 428 in 2011. Except for the two hamlets - Ic Ponor and Doda Pilii (from Mărgău Commune), and Fântânele Resort (Râșca Commune), respectively, for which we do not own individual data.

The results obtained from the spatial statistical analysis and the grouping analysis of the vacation homes, respectively, are shown in Table 1.

Table 1: The results of grouping analysis

\begin{tabular}{|c|c|c|c|c|c|}
\hline & Variable & Mean & Std. Dev. & Min. & Max. \\
\hline \multirow{4}{*}{$\begin{array}{l}\text { The overall } \\
\text { results: }\end{array}$} & Distance (m*) & 500.6 & 809.6 & 6 & 3697 \\
\hline & Density (KD**) & 50.4 & 27.9 & 3.8 & 110.5 \\
\hline & Distance $\left(m^{*}\right)$ & 139.1 & 190.2 & 6 & $1,405.2$ \\
\hline & Density $\left(K D^{* *}\right)$ & 30.7 & 14.0 & 3.8 & 54.2 \\
\hline \multirow[t]{2}{*}{ Group 2} & Distance $\left(\mathrm{m}^{*}\right)$ & 158.5 & 153.5 & 12 & 659.4 \\
\hline & Density $\left(K D^{* *}\right)$ & 79.4 & 16.9 & 55.8 & 110.5 \\
\hline \multirow[t]{2}{*}{ Group 3} & Distance $\left(\mathrm{m}^{*}\right)$ & $1,585.2$ & 242.2 & $1,060.9$ & $2,031.7$ \\
\hline & Density $\left(K D^{* *}\right)$ & 76.9 & 14.8 & 37.7 & 100.9 \\
\hline \multirow[t]{2}{*}{ Group 4} & Distance $\left(\mathrm{m}^{*}\right)$ & $2,994.2$ & 676.8 & $1,610.6$ & 3697 \\
\hline & Density $\left(K D^{* *}\right)$ & 30.2 & 13.4 & 10.8 & 45 \\
\hline
\end{tabular}


The largest number of vacation homes belongs to the group 1 with a share of $54 \%$, followed by group 2 with a proportion of $27 \%$, then by group 3 with a proportion of $14 \%$ and ultimately cluster 4 with the lowest number of vacation homes (a proportion of $5 \%$ ). Therefore, the results show four relatively distinct groups.



Figure 1: The Parallel Box Plot of the grouping results

For instance, the first group (group 1 in Table 1), with the highest share of vacation homes, is characterized by areas with a low density of vacation homes located a short distance from the local people's buildings.

The second group (group 2 in Table 1), which ranks second in the number of vacation homes, is described by areas with the highest density of vacation homes located a short distance from the local people's buildings.

The third group (group 3 in Table 1), with a smaller number of vacation homes than the previous one, comprises areas with a high density of vacation homes located a great distance from the local people's buildings.

The fourth group (group 4 in Table 1), with the lowest number of vacation homes, is described by areas with a low density of vacation homes located at the greatest distance from the local people's buildings.

It is interesting to note that the same settlement may include more than one group (for example the Beliș village, see Figure 2 and Figure 4). This outlines the spatial peculiarities of the second home development and, therefore, the need for a more detailed analysis. 


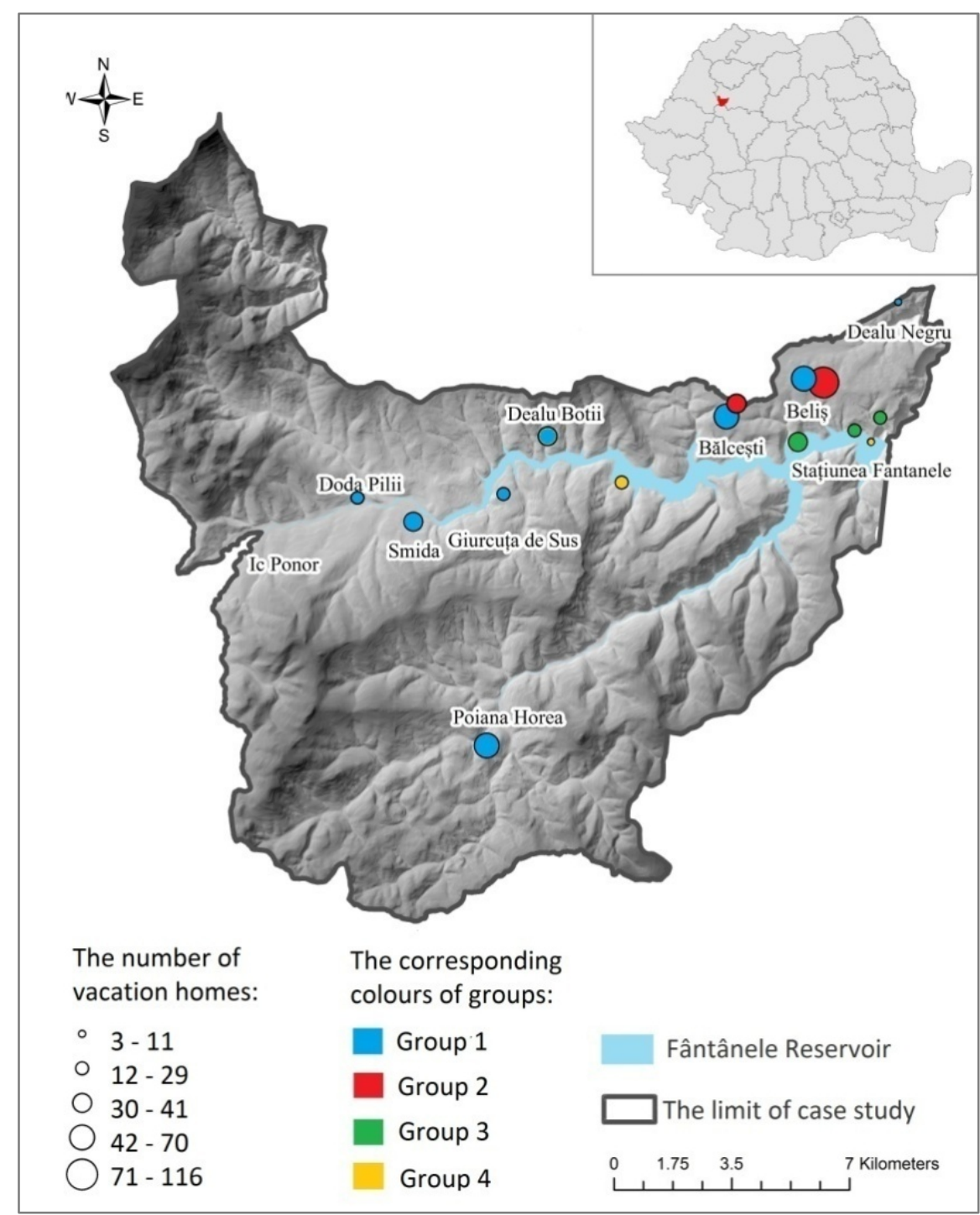

Figure 2: The spatial distribution of the grouping results in the case study of Apuseni Nature Park (part of Cluj County)

\section{Pattern 1 - Poiana Horea village (Beliș Commune, Cluj County)}

Poiana Horea is a village that, according to the Census of Population and Housing of 2011, registered 337 inhabitants, which represents a share of $27.8 \%$ of the total population of Belis Commune. However, the number of permanent residents is steadily declining. For instance, in the period between 1992 and 2002, there was a decrease of $-7 \%$ of the local population, and between 2002 and 2011 the number of inhabitants decreased by $-20 \%$.

The picturesque village with modest houses, mostly made of wood, seems to be the perfect combination of rural culture, historical heritage, and attractive natural landscapes. Moreover, based on the descriptions of Surd, Constantin \& Nicula (2017) and Conea (1937), the settlement falls into the category of those scattered with one core (see letter 'a' in Figure 3), with some dispersed buildings on the slopes. 
Moreover, it should be noted that some of the local population's buildings are either used only seasonally or are uninhabited (especially in the areas away from the village centre). Thus, in some locations, this can contribute to strengthening the private character of the place for the vacation home owners. Moreover, because of the development of vacation homes in some isolated areas, there is a slight tendency of spatial extension of the permanent settlement (see letter ' $b$ ' in Figure 3).

Though, compared to the other patterns in the paper, this one contains the vacation homes located (on average) at the shortest distance from the local people. Also, their spatial distribution between the houses of the inhabitants is relatively homogeneous and with low density.

In terms of place attachment, due to the physical proximity between the vacation homes and the permanent settlement, the emotional bonds of seasonal owners with the area can also be fostered by the local cultural and social landscape, in addition to the undeniable attractive natural



Figure 3: The spatial distribution of the group 1 in the case of Poiana Horea village (Beliș Commune, Cluj County) landscapes.

Moreover, in this pattern, there are several instances in which the former permanent homes were inherited and transformed into vacation homes. Therefore, in respect to these situations, Flemsæter (2009) states that "the relation may not only be one of leisure but also implies complex emotional dilemmas" (cited from Müller, 2011, p. 140). In addition, the presence of family roots in the area can also reduce cultural differences.

There are also a few isolated cases where locals' houses were bought by people in the urban area and turned into their own vacation homes. In our opinion, due to the fact that the vacation home owners spend their leisure time in a traditional house, this can lead to a more intensive and authentic experimentation of the rural life and consequently, to a better understanding of the cultural and social values of the place. 
In fact, given the existing housing stock and based on depopulation phenomena, such situations are more common in this type of development than in other areas where vacation homes are newly built and isolated from permanent settlements (see Figures 5 and 6 ).

On the other hand, if there are differences in opinion between the second home owners and the local people regarding the future developments, the physical vicinity (as Overvåg \& Berg, 2011 , claim) between the two groups may increase the possibility of conflicts.

However, due to the overall low density of houses and the scattered character of settlement, the work and leisure landscape situations, that some authors mention (see Halseth, 2004; Overvåg \& Berg, 2011; Stedman, 2006), may have a more smoother transition than in other places (see the next pattern).

Having said that, the relatively short distance favours an easier integration into the community by interacting with locals, participating in local events or cultural-religious traditions (e.g. the manifestation dedicated to Horea, the leader of the peasant uprising of 1784 that broke out in the Apuseni Mountains; see Kovacs, 2018). Moreover, the access to other social networks that Gallent (2014) mentions is much easier to achieve in this case.

In the same vein, given the physical proximity and the socio-economic status of vacation home owners (some of them have professions such as university professor and doctor), it is easier to attract valuable social capital in the area.

In this pattern, most vacation homes are built of wood and are small to medium in size. As such, if the socio-economic status of the second home owners is deducted from the structure and size of the vacation homes, in this pattern, the 'elite landscape' mentioned in the literature (Halseth, 2004 for example) is less visible than in some of the following models (e.g. pattern 2 and pattern 3 in Figures 4 and 5).

Spatial segregation is minimal in this type of second home development (with a slight tendency in the area mentioned above, see letter ' $b$ ' in Figure 3). After all, the low density, the short distance and the relatively uniform distribution of the secondary dwellings inside the permanent settlement did not encourage any spatial or social segregation of the two groups. However, due to physical proximity, in this pattern, locals are more susceptible to the risk of copying negative behaviours observed in second home owners.

Also, in this type of second home development, the potential conflicts caused by the overlap of the two markets in terms of housing and land stock do not seem to be justified. As in the case of Overvåg \& Berg (2011) in regard with mountain areas, the land areas are vast and the possibilities for purchasing empty homes are relatively high. Moreover, the locals seem eager to sell part of the land they own for an additional source of income.

Furthermore, the current context does not favour the displacement caused by residential tourism. In line with Marjavaara's (2007) conclusions, the population exodus in this pattern is rather because of limited economic and social opportunities in the area.

Moreover, based on the low density of vacation homes, the effect of the 'urbanized landscape' (see Mika, 2013) is minimal. Consequently, the 'ghost town' or the 'ghost village' situations indicated in the literature (Litvin et al., 2013; Overvåg \& Berg, 2011; Shucksmith, 1983) are less common. 


\section{Pattern 2 - Beliș village (Beliș Commune, Cluj County)}

Beliș is a relatively new village, relocated after the construction of the Fântânele Reservoir. This is reflected in the physical structure of the settlement which is much more organized than the neighbouring villages. It is the centre of Beliș commune, with a total population of 517 inhabitants in 2011 (according to the Census of Population and Housing, 2011), representing $28 \%$ of the total population of the Beliș Commune. The village registered a demographic decrease of $-12.5 \%$ in the period between 1992 and 2002 , and of $-1.5 \%$ in the period between 2002 and 2011, respectively.

The structure of permanent settlement is a compacted one (according to the descriptions of Conea, 1937 and Surd, Constantin \& Nicula, 2017). Also, the predilection of the locals towards the development of tourism is more obvious than in the previous case (many of the locals have properties that they rent to tourists).

Generally, the vacation homes are built on the outskirts of the village, in a setting with a wide view and a high quality of the natural landscape.



Figure 4: The spatial distribution of the groups 1 and 2 in the case of Beliș village (Beliș Commune, Cluj County)

In terms of the sense of place, the higher density of vacation homes located on the outskirts of the village may favour an attachment to the natural environment rather than to the rural social life of the local community. Thus, in this pattern, it is more obvious the individualization of the two groups, and the work versus the leisure landscapes often mentioned in the literature, respectively. In view of this, the closeness between the second home owners and the permanent inhabitants can increase the chances of conflicts.

Moreover, due to the implication of local people in tourism entrepreneurship, they may be disadvantaged by some of the seasonal homeowners who choose to rent their vacation homes occasionally.

Spatial segregation in this pattern is evident. It consists of four main clusters (see letters a, b, c, $d$ in Figure 4). Thus, against the background of the spatial separation of a high density of vacation home owners, a social interaction with the local inhabitants may be less probable. However, this type of spatial development fosters a social interaction of vacation home owners with family members, friends or relatives, or with other neighbouring vacation home owners. Also, the 
connection of the inhabitants with the external social systems (mentioned by Gallent, 2014) may be more difficult to achieve than in pattern 1 (Figure 3), mentioned before.

Moreover, if the socio-economic status of the second home owners is deducted from the structure and size of the vacation homes, in this pattern, the 'elite landscape' seems to be much more pronounced than in the previous model. The vacation homes in this case are more varied. They range from small chic wooden cottages to large masonry houses. Consequently, this can affect the traditional aesthetics of the built landscape of the settlement.

Moreover, because of the relatively high density of vacation homes, the effect of the 'urbanization of rural areas' as well as the change in the spatial and morphological character of the settlement mentioned by Mika (2013) are more visible in this pattern.

Regarding gentrification, due to the increasing number of vacation homes owners, it is more susceptible than the other, but there is no evidence in this regard. As in the first case, the depopulation phenomenon is not caused by residential tourism, but rather because of the social and economic context.

Moreover, due to the proximity of Cluj-Napoca (approximately $58 \mathrm{~km}$ ), where most vacation owners come from, the pattern can be considered a "weekend zone" (according to the classification of Hall \& Müller, 2004). This kind of development favours frequent and short-term visits to weekend homes. Therefore, such accessibility can create negative effects as well a significantly higher level of congestion or a lower chance of socialization with the locals due to the short periods spent in the area.

Also, in the off-season, the effect of 'ghost town' often mentioned in the literature is much more obvious than in the previous case. Consequently, this fact can lead to an increase in the crime rate.

In addition, the existence of the group 1 in this pattern may predict a future expansion of group 2 in those areas.

\section{Pattern 3 - Fântânele Resort (Râșca Commune, Cluj County) and other shoreline settlements of} the Fântânele Reservoir (Beliș Commune, Cluj County)

This pattern is representative for areas with a relatively large number of vacation homes located at a significant distance from permanent settlements. In our case it is about Fântânele Resort (Râșca Commune, see the letter ' $a$ ' in Figure 5) and an isolated cluster with vacation homes to which the access is made from Beliș village (Beliș Commune, see letter ' $b$ ' in Figure 5).

According to the literature, this type of development seems to be the most favourable pattern due to the compact spatial distribution of the vacation homes, and due to the great distance from the permanent settlements. As a result, in these cases, the two worlds 'leisure versus work landscapes' are not overlapped.

The nature of the attachment to the place seems to be fostered primarily by the qualities of the natural environment and by the leisure activities related to it. In fact, due to the long distance from the village, direct interactions with the local community are much more difficult to achieve (especially in the case of Fântânele Resort). Therefore, gaining social interaction and social capital in such areas can be a difficult goal to achieve, the main form of social interaction of the second home owners in this area being with family and relatives or friends or other neighbouring vacation home owners. 
Moreover, in the Fântânele Resort, the elite status is well consolidated both by the spatial isolation and by the socioeconomic status of the second home owners. In this case, the financial potential of the owners is obvious and is reflected in the high standard of vacation homes (perhaps the highest in the entire study area). However, the impact on the host communities is insignificant as long as the contact between the two groups is minimal.

Compared to Fantanele Resort, in the case of the cluster with the corresponding letter ' $b$ ' (see Figure 5), the vacation homes are represented by small to medium cottages built of wood. But this may also be due to poor road access or other urban planning restrictions given that it does not have the status of a resort as in the other case.

Anyway, regarding the possible conflicts caused by the

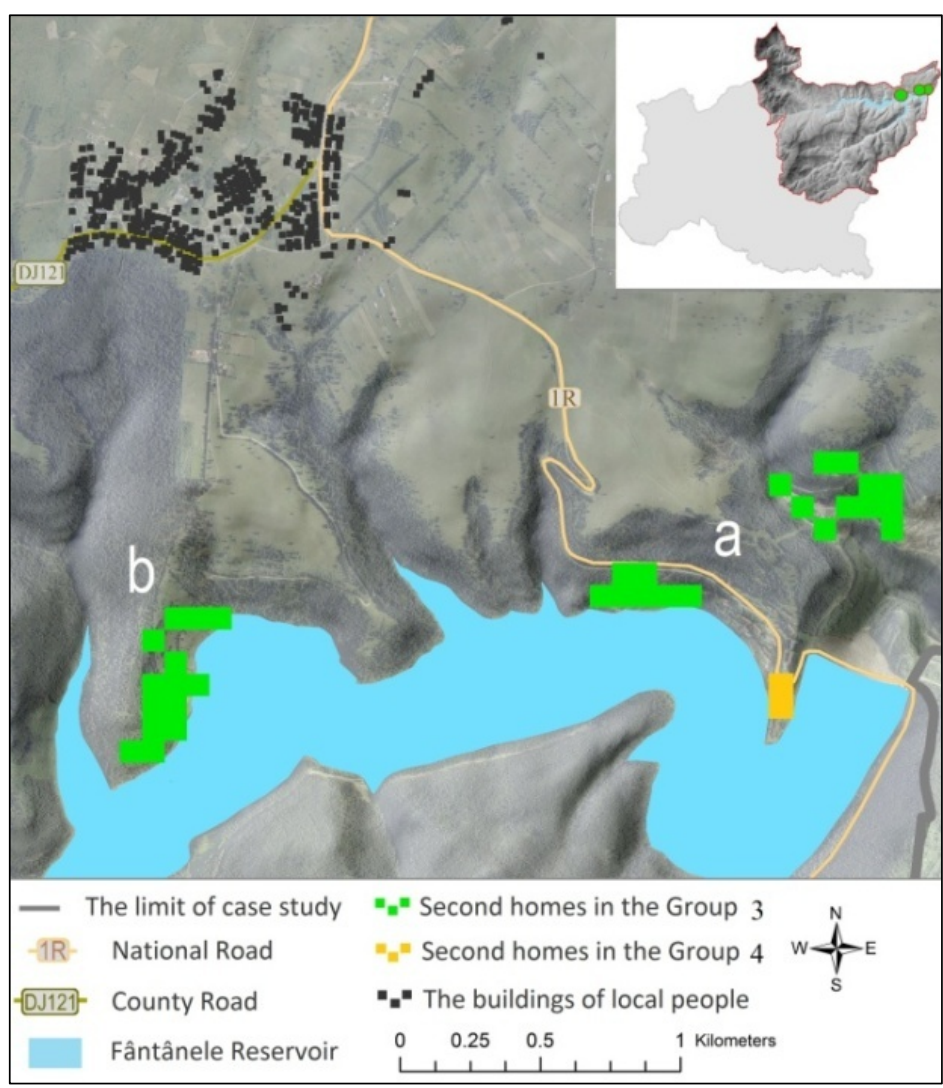

Figure 5: The spatial distribution of the groups 3 and 4 in the case of Fântânele Reservoir and other shoreline settlements with vacation homes (Beliș and Râșca Communes, Cluj County) competition for the same lands between the two groups, the issue of the 'land grabbing' (notion used by Cottyn, 2011, in the context of displacement phenomena) of the most attractive and accessible areas by the second home owners can be raised. Therefore, the conflicts can occur especially because in this area the locals are more interested in tourism entrepreneurship than in other neighbouring villages. Thereby, the vacation homeowners seem to monopolize the most attractive recreational areas.

\section{Pattern 4 - Shoreline settlements of the Fântânele Reservoir (Beliș Commune, Cluj County)}

In this model, the vacation homes are located (on average) at the greatest distance from the local people's buildings compared to all the previous models. This model is typical of owners who are followers of solitude. The place attachment can be favoured exclusively by the factors of the natural environment. In this model, the owners spend their free time through activities related to water, hiking, picking berries and other occupations related to nature or cottage. 
All vacation homes in this pattern are made exclusively of wood, most of them small. There are also several caravans used as vacation homes. As in the previous case (see letter $b$ in Figure 5), this is largely due to the fact that there is poor physical access (possible only through a forest road) or due to some restrictions of urban planning.

Also, the spatial scattering of vacation homes in these areas does not even encourage the direct social interaction between the second home owners' community. An exception to this is the cluster marked with 'a' (see Figure 6) in which there are several small wooden cottages located side by side. In this place, the vacation home owners are more likely to interact with each other, so that in season it seems they form a small community.

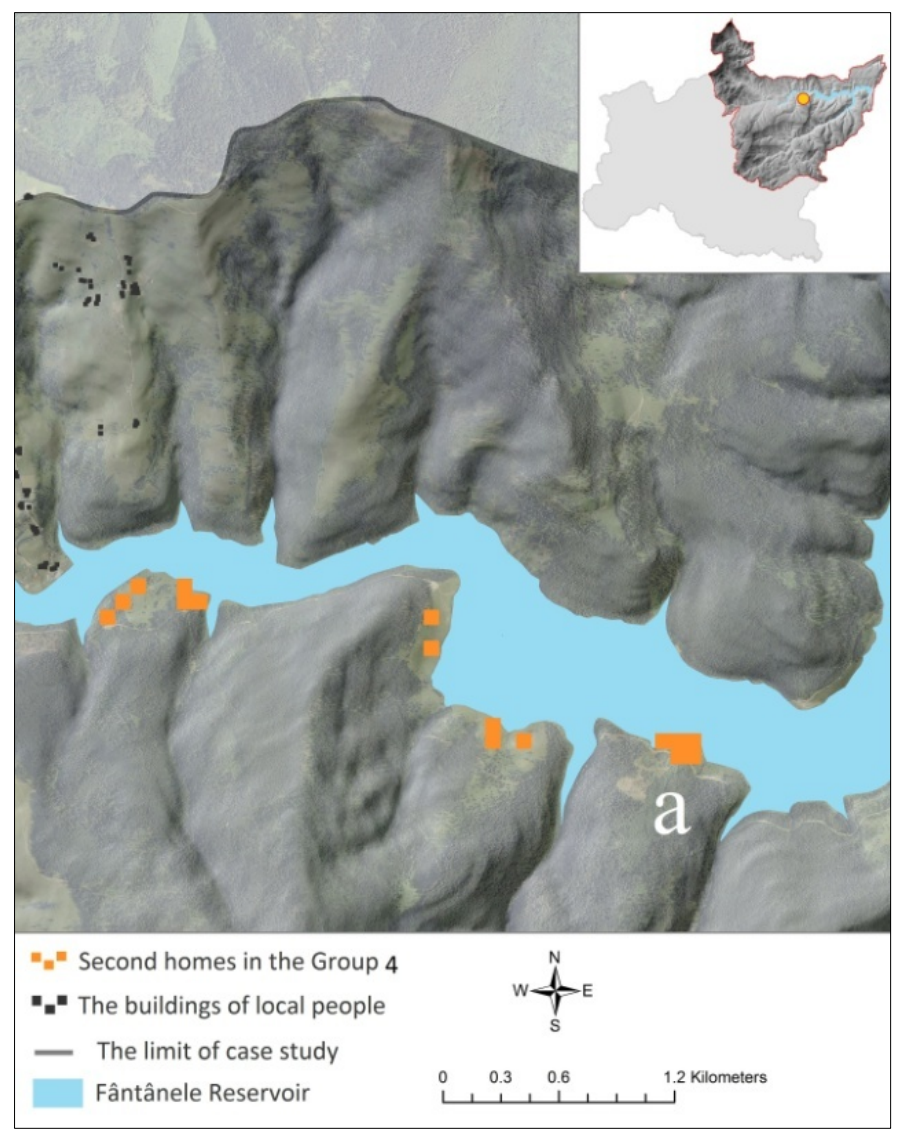

Figure 6: The spatial distribution of the group 4 in the case of shoreline settlements with vacation homes (Beliș Commune, Cluj County)

\section{CONCLUSIONS}

The main goal of the current study was to determine the possible socio-economic effects of residential tourism in relation to the spatial patterns of vacation home in the Apuseni Nature Park (part of Cluj County).

The results of this research support the idea put forward by Müller \& Hoogendoorn (2013) according to which "context is crucial for assessing second home-related problems" (p. 365). Thus, based on the literature review and a spatial statistical analysis, the study has shown that the spatial distribution of the vacation homes may suggest valuable clues about possible impacts in an area. Using two variables that we consider determinant - distance and density -, results show that the socio-economic impacts on the local communities are highly contextual (Table 2). 
Table 2: The factors and the intensity of the possible effects for each group (based on our own considerations according to the literature and the results of the spatial statistical analysis)

\begin{tabular}{|c|c|c|c|c|c|c|c|c|c|c|c|c|}
\hline \multirow[b]{2}{*}{ Related factors: } & \multirow[b]{2}{*}{$\mathrm{L}$} & \multirow[b]{2}{*}{ M } & \multirow[b]{2}{*}{$\mathrm{H}$} & \multicolumn{3}{|c|}{$\begin{array}{l}\text { Group } 2 \text { - } \\
\text { High Density } \\
\text { - Low } \\
\text { Distance }\end{array}$} & \multicolumn{3}{|c|}{$\begin{array}{l}\text { Group } 3 \text { - } \\
\text { High Density } \\
\text { - High } \\
\text { Distance }\end{array}$} & \multicolumn{3}{|c|}{$\begin{array}{l}\text { Group } 4 \text { - Low } \\
\text { Density - High } \\
\text { Distance }\end{array}$} \\
\hline & & & & L & M & $\mathrm{H}$ & L & M & $\mathrm{H}$ & L & M & $\mathrm{H}$ \\
\hline $\begin{array}{l}\text { Place attachment oriented to the } \\
\text { natural environment }\end{array}$ & & & 0 & & 0 & & & & 0 & & & C \\
\hline $\begin{array}{l}\text { Place attachment oriented to cultural } \\
\text { and social aspects of the local } \\
\text { community }\end{array}$ & & & 0 & 0 & & & 0 & & & 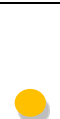 & & \\
\hline $\begin{array}{l}\text { Different perspective with regard to } \\
\text { the future development }\end{array}$ & & & 0 & & 0 & & 0 & & & $\Omega$ & & \\
\hline Social interaction and social capital & & & 0 & & 0 & & 0 & & & O & & \\
\hline Social segregation & & 0 & & & & 0 & & & 0 & & 0 & \\
\hline Spatial segregation & 0 & & & & & 0 & & & 0 & & & C \\
\hline Property market & 0 & & & 0 & & & & 0 & & $\Omega$ & & \\
\hline Displacement & 0 & & & 0 & & & 0 & & & 0 & & \\
\hline Gentrification & 0 & & & & 0 & & 0 & & & $\Omega$ & & \\
\hline Overdevelopment & 0 & & & & & 0 & & & 0 & $\Omega$ & & \\
\hline Seasonality & 0 & & & & & 0 & & & 0 & & & C \\
\hline Lost traditions & 0 & & & & & 0 & 0 & & & $\Omega$ & & \\
\hline
\end{tabular}

Therefore, four types of distinct patterns have resulted:

- Group 1, with low density of vacation homes located at short distance from the local people's buildings. Following the analysis, it is considered that through a rigorous community management at the local level, this model can be the least harmful for the socio-cultural aspects of the local community. The argument for supporting this idea is that only by the presence of the owners (in a limited number, of course) can positive effects be brought to the local community and not by their absence. Especially in communities such as our case, for which external infusions of social capital is welcome. In sum, we believe that against the background of low density, with careful planning and the involvement of local authorities, these vacation homes can be more easily 'absorbed' into the local community, thus bringing more socio-cultural benefits than disadvantages. So, in this case, we do not align with Overvåg \& Berg (2011) and Rye (2011) that claim that vacation homes should be kept away from local communities to avoid conflicts (we strongly emphasize that, only if their density is low).

- Group 2 is represented by a high density of vacation homes built in the immediate vicinity of permanent settlements. This, in our opinion, is the most harmful in terms of possible effects on local communities. Spatial and social separation does not facilitate social cohesion between the two groups. Here the feeling of 'us and them' mentioned by Nordin \& Marjavaara (2012, p. 296) is more accentuated. This model highlights the existence of two different worlds in the same place. However, in this model, the arguments of Overvåg \& Berg (2011) and Rye (2011), according to which the proximity of vacation homes to permanent settlements can generate negative effects on the local community, are argued. 
- Group 3 includes settlements with isolated vacation homes, in a large number and at a great distance from local communities. In general, these models are specific to the resorts (see, for instance, Fântânele Resort in our case). In this case, the socio-cultural impact is neutral. From our perspective, in this case, there are neither benefits (such as infusion with social capital, investment, financial support, social connection, socialization and so on), nor disadvantages.

- Group 4 belongs to settlements with a low density of vacation homes that are built at a great distance from permanent settlements. Against the background of its physical and morphological structure, in our vision, this model is the most 'neutral' scenario in terms of socio-cultural impact of second home tourism on local communities.

In conclusion, we consider that a spatial analysis of the possible social and cultural impact of residential tourism in an area can be an important tool in present and future planning processes. Still, though the current study has only examined the socio-cultural impact of residential tourism from a spatial perspective, in future research, an addition of a questionnaire-type approach applied to both vacation home owners and locals would be welcome.

\section{REFERENCES}

ASGARY, A., REZVANI, M.R., \& MEHREGAN, N. (2011). Local Residents' Preferences for Second Home Tourism Development Policies: A Choice Experiment Analysis. Tourismos: An International Multidisciplinary Journal of Tourism, 6(1), 31-51.

BORSDORF, A., HIDALGO, R., \& ZUNINO, H. (2012). Amenity Migration: A Comparative Study of the Italian Alps and the Chilean Andes. Journal of Sustainability Education, 3.

Retrieved 14 January 2020, from http://www.jsedimensions.org/wordpress/wpcontent/uploads/2012/03/BorsdorfHidalgoZuninoJSE2012.pdf

CONEA, I. (1937). Geografia satului românesc. Sociologie Românească, 2-3, 60-67, Retrieved 3 May 2020, from https://sas.unibuc.ro/storage/downloads/ion-conea-48/IC37.pdf

COPPOCK, J.T. (ed.). (1977). Second Homes: Curse or Blessing? Oxford: Pergamon.

COTTYN, I. (2011). The Spatial and Socio-Cultural Impacts of Second Home Development. A Case Study on Franschhoek, South Africa. Master Thesis, Utrecht University.

DUDLEY, N. (ed.). (2013). Guidelines for Applying Protected Area Management Categories, IUCN. Retrieved 12 May 2020, from https://portals.iucn.org/library/sites/library/files/documents/PAG-021.pdf

DYKES, S. \& WALMSLEY, A. (2015). The Reluctant Tourist? An Exploration of Second Home Owners' Perceptions of Their Impacts on North Cornwall, UK. European Journal of Tourism, Hospitality and Recreation, 6(2), 95-116.

FARSTAD, M. \& RYE, J.F. (2013). Second Home Owners, Locals and Their Perspectives on Rural Development. Journal of Rural Studies, 30, 41-51.

GALLENT, N. (2014). The Social Value of Second Homes in Rural Communities. Housing, Theory and Society, 31(2), 174-191.

HALL, C.M. \& MÜLLER, D.K. (2004). Introduction: Second Homes, Curse or Blessing? Revisited. In C.M. Hall \& D.K. Müller (eds.), Tourism, Mobility and Second Homes Between Elite Landscape and Common Ground (pp. 3-14). Clevedon, Buffalo, Toronto: Channel View Publication.

HALL, C.M. (2014). Second Home Tourism: An International Review. Tourism Review International, 18, Retrieved 22 January 2020, from

https://www.researchgate.net/profile/Colin_Hall5/publication/267812167_Second_Home_Tourism_An_Int ernational_Review/links/5a3106d30f7e9b0d50f929b5/Second-Home-Tourism-An-International-Review.pdf 
HALSETH, G. (2004). The 'Cottage' Privilege: Increasingly Elite Landscapes of Second Homes in Canada. In C.M. Hall \& D.K. Müller (eds.), Tourism, Mobility and Second Homes between Elite Landscape and Common Ground (pp. 35-54). Clevedon, Buffalo, Toronto: Channel View Publication.

HAO, H. \& LONG, P. (2016). Assessing Place Attachment among Permanent and Second Home Property Owners in an Tourism Dependent Coastal County. Travel and Tourism Research Association: Advancing Tourism Research Globally, 47.

Retrieved 5 May 2020, from https://scholarworks.umass.edu/cgi/viewcontent.cgi?article=1751\&context=ttra

JAAKSON, R. (1986). Second-Home Domestic Tourism. Annals of Tourism Research, 13(3), 367-391.

KALTENBORN, B.P. (1997). Nature of Place Attachment: A Study Among Recreation Homeowners in Southern Norway. Leisure Sciences: An Interdisciplinary Journal, 19(3), 175-189.

KONDO, M.C., RIVERA, R., \& RULLMAN, JR.S. (2012). Protecting the Idyll but not the Environment: Second Homes, Amenity Migration and Rural Exclusion in Washington State. Landscape and Urban Planning, 106(2), 174-182.

KOVACS, R. (2018). Dor de Horea, dor de autentic și de românesc. Retrieved 11 May 2020, from Radio Renașterea: https://radiorenasterea.ro/dor-de-horea-dor-de-autentic-si-de-romanesc/

LITVIN, S.W., XU, G., FERGUSON, A.C., \& SMITH, W.W. (2013). Too Attractive for Its Own Good? South of Broad, Second/Vacation-Homes and Resident Attitudes. Tourism Management Perspectives, 7, 89-98.

MANZO, L.C. \& PERKINS, D.D. (2006). Finding Common Ground: The Importance of Place Attachment to Community Participation and Planning. Journal of Planning Literature, 20(4), 335-350.

MARCOUILLER, D.W., GREEN, G.P., DELLER, S.C., SUMATHI, N.R, \& ERKKILA, D. (1996). Recreational Homes and Regional Development. A Case Study from the Upper Great Lakes States. University of Wisconsin Extension, Report No. G3651

MARJAVAARA, R. (2007). The Displacement Myth: Second Home Tourism in the Stockholm Archipelago. Tourism Geographies, 9(3), 296-317.

MATARRITA-CASCANTE, D., STEDMAN, R., \& LULOFF, A.E. (2010). Permanent and Seasonal Residents' Community Attachment in Natural Amenity-Rich Areas. Exploring the Contribution of Landscape-Related Factors. Environment and Behavior, 42(2), 197-220.

MCHUGH, K.E. (2006). Citadels in the Sun. In N. McIntyre, D.R. Williams, \& K.E. McHugh (eds.), Multiple Dwelling and Tourism. Negotiating Place, Home and Identity (pp. 262-277). Wallingford: CABI.

MCHUGH, K.E. (2007). Generational Consciousness and Retirement Communities. Population, Space and Place, 13, 293-306.

MCHUGH, K.E., \& MINGS, R.C. (1996). The Circle of Migration: Attachment to Place in Aging. Annals of the Association of American Geographers, 86(3), 530-550.

MIKA, M. (2013). Spatial Patterns of Second Homes Development in the Polish Carpathians. In J. Kozak, K. Ostapowicz, A. Bytnerowicz, \& B. Wyżga (eds.), The Carpathians: Integrating Nature and Society Towards Sustainability (pp. 497-512). Berlin, Heidelberg: Springer.

MÜLLER, D.K. \& HOOGENDOORN, G. (2013). Second Homes: Curse or Blessing? A Review 36 Years Later. Scandinavian Journal of Hospitality and Tourism, 13(4), 353-369.

MÜLLER, D.K. (2011). Second Homes in Rural Areas: Reflections on a Troubled History. Norsk Geografisk Tidsskrift Norwegian Journal of Geography, 65(3), 137-143.

MÜLLER, D.K., HALL, C.M., \& KEEN, D. (2004). Second Home Tourism Impact, Planning and Management. In C.M. Hall, \& D.K. Müller (eds.), Tourism, Mobility and Second Homes Between Elite Landscape and Common Ground (pp. 15-32). Clevedon, Buffalo, Toronto: Channel View Publication.

NATIONAL AGENCY FOR CADASTRE AND REAL ESTATE ADVERTISING (2019). Geoportal ANCPI. Retrieved 3 January 2020, from https://geoportal.ancpi.ro/geoportal/catalog/download/download.page

NORDIN, U. \& MARJAVAARA, R. (2012). The Local Non-locals: Second Home Owners Associational Engagement in Sweden. Tourism, 60(3), 293-305.

NORRIS, M. \& WINSTON, N. (2009). Social, Economic and Environmental Impacts of Second Homes in Ireland. In S. Tsenkova (ed.), Planning Sustainable Communities Diversity of Approaches and Implementation Challenges (pp. 149-168). Calgary: University of Calgary, Faculty of Environmental Design. 
OVERVÅG, K. \& BERG, N.G. (2011). Second Homes, Rurality and Contested Space in Eastern Norway. Tourism Geographies: An International Journal of Tourism Space, Place and Environment, 13(3), 417-442.

PARIS, C. (2009). Re-positioning Second Homes within Housing Studies: Household Investment, Gentrification, Multiple Residence, Mobility and Hyper-consumption. Housing, Theory and Society, 26(4), 292-310.

ROMANIA RPL - Census of Population and Housing of 2011 - Romania. Retrieved 14 June 2016, from http://www.recensamantromania.ro/en/

ROMANIAN MINISTRY OF ENVIRONMENT, WATER AND FORESTS (2015). GIS Data. Retrieved 3 May 2020, from http://www.mmediu.ro/articol/date-gis/434

RYE, J.F. (2011). Conflicts and Contestations. Rural Populations' Perspectives on the Second Homes Phenomenon. Journal of Rural Studies, 27, 263-274.

SHUCKSMITH, D.M. (1983). Second Homes: A Framework for Policy. Town Planning Review, 54 (2), 174-193.

STEDMAN, R.C. (2006). Understanding Place Attachment among Second Home Owners. American Behavioral Scientist, 50(2), 187-205.

SULLIVAN, D.A. \& STEVENS, S.A. (1982). Snowbirds: Seasonal Migrants to the Sunbelt. Research on Aging, 4(2), $159-177$.

SURD, V., CONSTANTIN, V., \& NICULA, A.S. (2017). Așezările din Munții Apuseni [Settlements of the Apuseni Mountains]. Cluj-Napoca: Presa Universitară Clujeană.

SURD, V., ZOTIC, V., PUIU, V., \& MOLDOVAN, C. (2014). Riscul demografic în Munții Apuseni [Demographical Risk in the Apuseni Mountains]. Cluj-Napoca: Presa Universitară Clujeană.

TRENTELMAN, C.K. (2009). Place Attachment and Community Attachment: A Primer Grounded in the Lived Experience of a Community Sociologist. Society \& Natural Resources, 22(3), 191-210.

WOODS, M. (2005). Rural Geography: Processes, Responses and Experiences in Rural Restructuring. Los Angeles, London, New Delhi, Singapore, Washington DC: Sage. 